\title{
Academic Life Assessment Scale (ALAS): A new factorial structure
}

\author{
Acácia Aparecida Angeli dos Santos ${ }^{1}$ \\ Francine Náthalie Ferraresi Rodrigues Quelur' \\ Ana Carolina Pescarini Gallo ${ }^{2}$ \\ Thalyta Hulsen Lemos Veiga ${ }^{1}$ \\ ${ }^{1}$ Universidade São Francisco, Campinas, SP \\ ${ }^{2}$ Universidade Paulista - UNIP, Campinas, SP
}

\begin{abstract}
The objective of the present study was to give continuity to the validation process of the Academic Life Assessment Scale (ALAS) by verifying its internal structure and the relationship with other related variables. The study involved 580 undergraduate students from two universities in the state of Paraíba, one public and one private. A majority of the participants were male $(55 \%)$ with an average age of $22(S D=4.94)$ who responded to the ALAS and the Academic Experience Questionnaire Reduced (AEQ-r). To verify the internal structure of the ALAS, first, a confirmatory factor analysis was performed and, as the structure was not confirmed, an exploratory factor analysis (EFA) was performed. After EFA, a three-factor model was found, which presented good reliability, as well as correlation with academic experiences measures. This study contributes to the literature suggesting a new factorial structure for ALAS.

Keywords: academic adaptation; undergraduate students; higher education; psychometry
\end{abstract}

Escala de Avaliação da Vida Acadêmica (EAVA): Uma Nova Estrutura Fatorial

\section{Resumo}

O objetivo do presente estudo foi dar continuidade ao processo de validação da Escala de Avaliação da Vida Acadêmica (EAVA) por meio da verificação de sua estrutura interna e da relação com outras variáveis correlatas. Participaram do estudo 580 estudantes universitários de duas universidades do estado da Paraíba, sendo uma pública e uma privada. Os participantes foram compostos por maioria masculina (55\%), com idade média de 22 anos (DP $=4,94)$ que responderam à EAVA e ao Questionário de Vivências Acadêmicas Reduzido. Para verificar a estrutura interna da EAVA, primeiro foi realizada uma análise fatorial confirmatória e, uma vez que a estrutura não foi confirmada, foi realizada a análise fatorial exploratória (EFA). Após a EFA, identificou-se um modelo com três fatores, que apresentou boa confiabilidade, além de se correlacionar com as medidas de vivências acadêmicas. Este estudo contribuiu para a literatura ao sugerir uma nova estrutura fatorial para a EAVA.

Palavras-chave: adaptação acadêmica, universitários, ensino superior, psicometria

\section{Escala de Evaluación de la Vida Académica (EEVA): Una nueva estructura factorial}

\begin{abstract}
Resumen
El objetivo del presente estudio fue dar continuidad al proceso de validación de la Escala de Evaluación de la Vida Académica (EEVA) por medio de la verificación de su estructura interna y de la relación con otras variables relacionadas. Participaron 580 estudiantes universitarios de dos universidades del estado de Paraíba, una pública y otra privada. Los participantes eran la mayoría de sexo masculino (55\%), con edad promedio de 22 años (DP $=4,94$ ) que respondieron a la EEVA y al Cuestionario de Vivencias Académicas Reducido. Para verificar la estructura interna de la EEVA, primero se realizó un análisis factorial confirmatorio y una vez que la estructura no fue confirmada, se realizó el análisis factorial exploratorio (EFA). Después de la EFA, se encontró un modelo con tres factores, que presentó buena confiabilidad, además de correlacionarse con las medidas de vivencias académicas. Este estudio contribuyó con la literatura, al sugerir una nueva estructura factorial para la EEVA.

Palabras clave: adaptación académica; universitarios; Enseñanza Universitaria; psicometría
\end{abstract}

As high school ends, the student is faced with a decision: to enter the job market without specializing or pursue higher education in search of professional training capable of delivering social success. The number of students in the Brazilian university sphere has increased exponentially in recent decades (Chacon \& Calderón, 2015) and, given the multiplicity and heterogeneity of this audience, it is necessary to understand and gauge their perception of academic life.
A student's integration into university life, especially with regard to his/her academic performance, is associated with personal characteristics, the institutional environment, and the interaction between them (Douglass \& Duffy, 2015; Tinto, 1975; Vendramini et al., 2004). Soares and Almeida (2001) understand that academic lives reflect the level of the students' integration, referring to the intensity of students' cognitive and behavioral investment in relation to academic 
activities. In turn, Fior, Mercuri and Silva (2013) define academic lives through university students' participation in educational tasks. Scholars in this area consider integration in higher education stems from an interactive process between different attributes, such as personal resources, institutional characteristics and interaction groups (Douglass \& Duffy, 2015, Ganguly, 2017 and Polydoro 2000).

Personal resources are related to the student's prior history and abilities, such that he/she has a basis for studying higher education disciplines, as well as support for day-to-day access, whether financial, familial, or peer support. Institutional characteristics are related to the particular institution at which the student is enrolled, compulsory and non-compulsory didactic activities, and any other type of support regarding the teaching/learning process that the student may need. Finally, group interaction concerns the circles in which the student is inserted, either within or outside the university, which can contribute to his/her learning, such as: academic centers, research groups, organized sports or events, among others (Ganguly, 2017 and Polydoro, 2000).

In this same vein, some models are proposed to explain characteristics inherent in academic life and how they interrelate. Among them, the best-known models are Astin (1999) and Tinto (1975, 1997). The former argues that student involvement must be measured by the amount of physical and psychological energy that the student spends in order to achieve the desired educational outcomes. For Astin (1999), the student's effort is proportional to the probability of remaining in university and succeeding. The Tinto model (1997) argues the existence of four factors that interact with each other and influence the student's permanence and success in the university, including: (1) preliminary characteristics, which is the student's history involving family and social context and previously acquired skills; (2) institutional characteristics, which relate to place of enrollment, campus specifics, disciplines offered, and resources that accessible through the university, among others; (3) academic integration, which pertains to how the student interacts and integrates with the institutional body, whether professors or staff, and finally, (4) social integration, which involves the student's involvement in extracurricular activities. Both models defend the student as actuator of his/her own life, being responsible for academic success and permanence in the university.

Also aiming to understand the relationship between academic lives, motivations for attrition, and career adaptability among university students, Ambiel, Santos and Dalbosco (2016) conducted a study with 153 university students, in which they tested a theoretical model with these three constructs to verify how they related to each other. The authors conclude that exploratory behaviors in an academic environment and of the student himself contribute to a real understanding of the chosen profession. In addition, the student's expectation of the career and the way he/she feels when attending classes on a daily basis may be strongly related to the decision to remain or withdraw from the course, according to the theoretical models presented above, as well as other studies in the area (Astin, 1999; Douglass \& Duffy, 2015; Fior, Merci, \& Silva, 2013; Oliveira, Santos, \& Dias, 2016; Tinto, 1997; Vendebenito, 2017).

In addition to studies on the compulsory activities of the course, Fior and Mercuri (2009) sought to understand the contribution of non-compulsory activities in the academic training process through interviews with 16 university students. The participants reported that the optional activities are fundamental in their professional training, among them: the participation in scientific projects, internships, study groups for problem-solving exercises, monitoring, participation in collegiate bodies, conferences and study weeks, which propelled them in the process of academic formation. We also highlight the interpersonal relationships in the academic space that contribute to the development of the future professionals' social skills through the relationship between their abilities and their academic performance.

Given the above, it is important that these characteristics that comprise academic life can be evaluated. As Ambiel et al., (2016) point out, assessment in this context is of fundamental importance in order to predict the student's permanence and/or performance throughout the course and to intervene before a problem that impairs the student's academic life can intensify. From this perspective, the development of a scale aimed at describing inherent actions in the student's academic life, as well as their integration into the context of higher education, is relevant as it will allow understanding of the various dimensions involved in the college students' experience regardless of course.

Internationally, there are instruments that aim to measure the academic and social integration of the student, such as the College Student Experiences Questionnaire (CSEQ), with the objective of evaluating the student's social and intellectual development as well as his involvement in academic activities, compulsory and 
non-compulsory, and quality of this involvement (Pace \& Kuh, 1998). Another widely-used instrument in the international context is the Student Development Task and Lifestyle Inventory (SDTLI), with the objective of identifying the behaviors that students emulate to reach their goals, to maintain healthy relationships, and academic autonomy (Winston, Miller \& Prince, 1987). The two instruments question students' participation in compulsory and non-compulsory activities, as well as their relationship with the institution in which they are enrolled and with the people in their social circle.

With a similar purpose and seeking to understand how academic life unfolds, Santos, Polydoro, Vendramini, Natário and Serpa (2003) constructed the Academic Life Assessment Scale (ALAS), considering the Brazilian context. The purpose of the ALAS is to evaluate the student's perception of his/her university experience. The scale was built on international theoretical bases to identify the experiences lived by university students (Almeida et al., 1999; Pascarella \& Terenzini, 1991). It also considered national research that focused on the understanding of facts that involve university students when faced with the demands of higher education (Polydoro, 2000; Polydoro \& Primi, 2001). In addition, the ALAS seeks to assess, through contextual, interactional and personal aspects, how integrated into the academic life the student perceives himself to be.

In a study conducted by Vendramini et al., (2004) with 1,118 university students, a five-factor structure was found for the ALAS, including: Factor 1 - university environment - associated to the specific context of the university environment, involving physical, social and organizational characteristics $(\alpha=0.73)$; Factor 2 - commitment to the course - related to the student's conviction regarding the course selection and confidence in the professional training offered by it $(\alpha=$ 0.79); Factor 3 - studentss ability - refers to academic potential, considering school background, basic skills and personal qualities ( $\alpha=0.80$ ); Factor 4 - involvement in non-compulsory activities - groups formal course activities that, even if complementary, add knowledge and experience to the student's education, being thus encouraged by the university $(\alpha=0.71)$; Factor 5 - conditions for study and academic performance - integrates study conditions including physical and psychological energy, as well as the time invested by the student in the academic tasks $(\alpha=0.63)$.

Considering the measured psychometric properties, with satisfactory results in terms of internal consistency, verification of whether the model found by
Vendramini et al., (2004) could be confirmed in another sample was shown to be relevant. Thus, the objective of the present study was to continue the validation process of the ALAS by verifying its internal structure and the relationship with related variables. In this sense, we investigated evidence of internal validity, in relation to the internal structure and accuracy of the instrument (factorial structure and reliability) and validity evidence based on the relation with other variables (through the analysis of measures that evaluate related constructs, academic life). We expected that the five-factor structure found by Vendramini et al., (2004) was confirmed and ALAS scores, both general and in the factors, correlated positively with the scores of the Academic Experiences Questionnaire (AEQ-r) (Granado, Santos, Almeida, Soares, \& Guisande, 2005).

\section{Method}

\section{Participants}

A total of 580 university students participated in this study, with a mean age of 22 years $(S D=4.94)$, ranging from 18 to 61 years old, from two universities in the state of Paraíba, one public (51.2\%) and one private (48, $8 \%$ ). Most of the participants were male (55\%), single $(86.8 \%)$, studied full-time $(32 \%)$ or in morning programs (29.7\%), and majored in Physical Education (20.9\%), Architecture and Urbanism (15.7\%), Psychology (14.5\%), or Physiotherapy (10.2\%). In addition, of the total number of participating students, $99.3 \%$ planned to continue their current course, and $40.5 \%$ had some type of paid activity. As inclusion criteria, participants had to be over 18 years of age and be enrolled in higher education. The sociodemographic data of the participants is presented in Table 1.

\section{Instruments}

The instruments used in this study will be described below. First, a sociodemographic questionnaire was applied, followed by the Academic Experiences Questionnaire and the Academic Life Assessment Scale.

Sociodemographic Questionnaire - A set of items was designed to verify characteristics such as gender, age, marital status, and course, among others. The participants in the sample were described through these means.

Academic Life Assessment Scale - ALAS (Santos et al., 2008). The scale is comprised of 34 items with a 5-point Likert scale ranging from: "I totally disagree" (1 point), "Disagree" ( 2 points), "Indifferent" 
Table 1.

Sociodemographic profile of the participants

\begin{tabular}{|c|c|c|c|}
\hline Variable & & $\mathrm{N}$ & $\%$ \\
\hline \multirow[t]{2}{*}{ Sex } & Female & 261 & 45.0 \\
\hline & Male & 319 & 55.0 \\
\hline \multirow[t]{3}{*}{ Marital Status } & Single & 496 & 86.9 \\
\hline & Married/ Committed relationship & 69 & 12.1 \\
\hline & Separated/Divorced & 6 & 1.0 \\
\hline \multirow[t]{8}{*}{ Course } & Physical Education & 121 & 20.9 \\
\hline & Architecture and Urban Design & 91 & 15.7 \\
\hline & Psychology & 84 & 14.5 \\
\hline & Physiotherapy & 80 & 13.8 \\
\hline & Law & 59 & 10.2 \\
\hline & Engineering & 50 & 8.6 \\
\hline & Computer Science & 49 & 8.4 \\
\hline & Education & 16 & 7.9 \\
\hline \multirow[t]{4}{*}{ Class sessions } & Morning & 172 & 29.7 \\
\hline & Afternoon & 99 & 17.1 \\
\hline & Evening & 123 & 21.2 \\
\hline & Full-time & 185 & 32.0 \\
\hline \multirow[t]{2}{*}{ Institution } & Private university & 283 & 48.8 \\
\hline & Public university & 297 & 51.2 \\
\hline
\end{tabular}

(3 points), "Agree" "I totally agree" (5 points). The ALAS is composed of five factors: Factor 1 - university environment ( $\alpha=0.73$ ); Factor 2 - commitment to the course $(\alpha=0.79)$; Factor 3 - student's ability ( $\alpha$ $=0.80)$; Factor 4 - involvement in non-compulsory activities $(\alpha=0.71)$; Factor 5 - conditions for study and academic performance $(\alpha=0.63)$. The total reliability of the instrument was $\alpha=0.87$ (Vendramini et al., 2004). Regarding the score, the higher the score obtained in the scale, the more integrated the student is in the academic environment.

Academic Experiences Questionnaire (AEQ-r, originally QVA-r) The original instrument was developed in Portugal by Almeida, Soares and Ferreira (2002), and was adapted for use in Brazil by Granado et al., (2005). It employs a 5-point Likert scale, ranging from "Has nothing to do with me" (1) to "Has everything to do with me" (5). In the Brazilian version, the AEQ-r has 55 items distributed in five factors: Personal $(\alpha=0.87)$, Interpersonal $(\alpha=0.86)$, Career $(\alpha=0.91)$, Study $(\alpha=$ $0,82)$ and Institutional $(\alpha=0.71)$. The overall AEQ-r score also presented a good reliability index $(\alpha=0.88)$. The minimum score is 55 points and the maximum score is 275 .

\section{Data collection procedure}

After ethics committee approval, participating universities were contacted and, after approval from the institutions, the instrument applications were scheduled. Applications were carried out collectively in study participants' classrooms. The data collection took place in a single session for each class (that is, with all students in the same classroom), and respondents answered individually to the questionnaires, concomitantly. Thus, there was a single collection with each class, not exceeding the 50-minute class period. Before starting the data collection, participants read and signed the Terms of Free and Informed Consent (TCLE). The instruments were presented in the same sequence for all participants, namely: the sociodemographic questionnaire was first, then the ALAS and the AEQ-r. 


\section{Data analysis procedure}

In order to verify the score distributions for each instrument, the mean, standard deviation, minimum and maximum values, as well as kurtosis and asymmetry indicators for each variable were calculated. Descriptive analyses were performed using the Statistical Package for Social Sciences (SPSS), version 20. All variables had a normal distribution, according to the Kolmogorov-Smirnov normality test and following the recommendations of Marôco (2014) and Pasquali (2015).

To test the model proposed by Vendramini et al., (2004), confirmatory factorial analysis (CFA) was performed in MPLUS software. Adjustment indices considered for the CFA were: Comparative Fit Index (CFI $\geq 0.90)$, Root Mean Square Error of Approximation (RMSEA, $\leq 0.06$, with $90 \%$ confidence interval), Tucker-Lewis Index (TLI $\geq 0.95$ ), the statistical significance of the Chi-square test $(\mathrm{p} \leq 0.05)$ and the chi-square divided by the degree of freedom $\left(x^{2}\right)$ $\mathrm{gl}<3$ ) (Hu \& Bentler, 1999). In order to perform the exploratory factor analysis (EFA) in the second part of the study, the Factor program was used, considering the following adjustment indices provided by the program: Comparative Fit Index (CFI $\geq 0.90)$, Root Mean Square Error of Approximation (RMSEA $\leq 0.06$, with a confidence interval of $90 \%$ ), and the chi-square divided by the degree of freedom $\left(x^{2} / \mathrm{gl}<3\right)$. As it was an EFA, the significance values of $p$ and TLI were not considered (Marôco, 2014). To evaluate the reliability of the instrument, Cronbach's alpha calculation was used and to verify possible correlations, analyses were performed using the Pearson correlation test, calculated through SPSS 20. For the present study, the magnitude of the correlations was classified as weak $(<0.30)$, moderate $(0.30$ to 0.59$)$, strong ( 0.60 to 0.90$)$ or perfect $(1.0)$ (Levin \& Fox, 2004).

\section{Ethics procedures}

The project was approved by the Ethics Committee (Information Retrieved by the Journal). All participants received information about the research objectives, the activities to be developed and their rights, before signing the Terms of Free and Informed Consent. The identity of the participants was kept confidential.

\section{Results}

\section{Confirmatory Factor Analysis}

Table 2 shows the adjustment indices obtained after the confirmatory factorial analysis of the ALAS model proposed by Vendramini et al., (2004). According to the results observed in Table 2, it can be seen that the model proposed by Vendramini et al., (2004) was not confirmed, since $x^{2}$ presented a statistically significant value, which means that the previously proposed model differs from the model obtained by the sample in this study. In addition, when considering other adjustment indices, the CFI and TLI also did not present adequate values. The only indices that presented adequate values for the model to be confirmed were $x^{2} / \mathrm{gl}$ and RMSEA (Hu \& Bentler, 1999). Therefore, a decision was made to carry out a new exploratory factorial analysis for the ALAS to verify what factorial structure would be found.

\section{Exploratory Factor Analysis}

The sample for conducting the exploratory factor analysis focused on all participants $(\mathrm{N}=580)$. The first step was to check if the data matrix was factorizable by KMO (the Kaiser-Meyer-Olkin criterion), which was 0.85. As this value proved adequate (Damásio, 2012), the next step was to carry out factor retention. The extraction method was Robust Unweighted Least Squares, with Promin rotation method. The factors were extracted using the result of the Parallel Analysis and the Hull Method (Damásio, 2012). The parallel analysis indicated a solution with 3 factors and the Hull Method indicated a one-factor solution. From this, EFAs were performed on the two solutions to verify which fit best theoretically, also considering the adjustment indices for each one. In each EFA, the exclusion

Table 2.

Adjustment indices of the ALAS model proposed by Vendramini et al., (2004) presented at the AFC.

\begin{tabular}{lccccc}
\hline Model & $x^{2} / \mathrm{gl}$ & $p$ & CFI & RMSEA & TLI \\
\hline Reference Value & $<3$ & $\leq 0.05$ & $\geq 0.90$ & $\leq 0.06$ & $\geq 0.95$ \\
Five Factors & 2.66 & 0.001 & 0.81 & 0.05 & 0.79 \\
\hline
\end{tabular}

Psico-USF, Bragança Paulista, v. 25, n. 1, p. 1-13, jan. / mar. 2020 
criteria for items were to remove items that did not saturate at least 0.40 or that showed saturation in more than one factor (as in the case of the three-factor solution), until no item needed to be excluded.

In the one-factor structure, the KMO value was 0.85. In the first round, 13 items $(1,4,5,8,9,11,12$, $12,23,26,28,29$ and 30) did not saturate at any factor and were withdrawn. In the second round, two items (6 and 20) were withdrawn because they did not present the minimum saturation. In the third round, two more items (32 and 33) were withdrawn because they did not saturate the minimum load and finally, in round four, item 18 was withdrawn because it also did not present the minimum saturation. In the fifth round, no items needed to be deleted. At the end, the single-factor structure presented $37.75 \%$ of total variance explained, and the only adjustment index that presented adequate value was the CFI, as can be seen in Table 3 .

In the three-factor structure, the KMO value was also 0.85 , allowing factorization of the matrix. In the first round of the EFA for this model, eight items $(5,18,23,25,28,29,30$ and 31) were withdrawn as they did not saturate the minimum value by any factor. In the second round, three items (9, 15 and 20) were withdrawn because they did not present the minimum saturation. In the third round, no items needed to be deleted. However, in the third round, item 22 presented a saturation of 0.33 , but since it presented theoretical coherence in the factor in which it was included, the authors of the present study chose to keep the item in the scale. The other items that remained in the study had a factorial load lower than 0.15 in factors to which they were not allocated. At the end, the three-factor structure presented $50.35 \%$ of the total variance explained, and the adjustment indices were adequate, considering the values $x^{2} / \mathrm{gl}$, CFI and RMSEA. Thus, after comparing the solutions obtained, the adequacy to the conceptual model and to the statistical model, the solution that was most satisfactory was three-factor structure. Factor 1 was interpreted as mirroring a dimension of Student's Ability; Factor 2 as Involvement in Non-compulsory Activities; and Factor 3 as Commitment to the Course.

The correlation between the total score and all the ALAS factors is shown in Table 4, showing that all correlations were statistically significant and that all factors showed strong correlation with the Total ALAS Score. Among the factors, the correlation between Factor 1 and Factor 3 were of moderate magnitude, and between Factor 2 and Factors 3 and 1, the correlations were of weak magnitude.

Table 5 shows the final model with three factors and 23 items (according to the numbering of the old version of the ALAS) after the exploratory factor analysis and their respective saturation loads. In the present study, for Factor 1, $\alpha=0.78$, for Factor $2, \alpha=0.76$ and for Factor 3, $\alpha=0.63$. All are considered adequate for an exploratory factor analysis (Tornimbeni, Pérez, $\&$ Olaz, 2008). Cronbach's alpha overall $(\alpha=0.81)$

Table 3.

Adjustment indices obtained in EFAs performed in the present study

\begin{tabular}{lccc}
\hline Model & $x^{2} / \mathrm{gl}$ & CFI & RMSEA \\
\hline Reference Value & $<3$ & $\geq 0.90$ & $<0.08$ \\
Three Factors & 1.83 & 0.98 & 0.04 \\
Uni-factorial & 5.53 & 0.94 & 0.09 \\
\hline
\end{tabular}

Table 4.

Correlations between the Total ALAS Score and their Three-Factor Scores

\begin{tabular}{lccc}
\hline & Total score & Factor 1 & Factor 2 \\
\hline Factor 1- Student's Ability & $0.74^{*}$ & & \\
Factor 2 - Involvement in optional activities & $0.67^{*}$ & $0.24^{*}$ & \\
Factor 3 - Dedication to the course & $0.67^{*}$ & $0.41^{*}$ & $0.24^{*}$ \\
\hline
\end{tabular}

${ }^{*}=p<0.01$ 
was excellent. The current version of the ALAS with renumbered items is attached as well as the items that must be reversed.

Validity evidence based on relationships with other variables for the new ALAS factorial structure

Through the Pearson test, correlations were calculated between the factors and the total ALAS score, with the factors and total score of the AEQ-r. The results are shown in Table 6.

Table 5.

Saturation of ALAS Items by Factor and their reliability values

\begin{tabular}{lc}
\hline Factor/Items & Saturation \\
\hline Factor 1 - Student's Ability & $\boldsymbol{\alpha}=\mathbf{0 . 7 8}$ \\
\hline Item 4 & 0.56 \\
Item 7 & 0.50 \\
Item 8 & 0.47 \\
Item 10 & 0.59 \\
Item 12 & 0.68 \\
Item 13 & 0.57 \\
Item 14 & 0.53 \\
Item 19 & 0.68 \\
Item 21 & 0.63 \\
Item 27 & 0.57 \\
\hline Factor 2- Involvement in Non- & $\boldsymbol{\alpha}=\mathbf{0 . 7 6}$ \\
compulsory Activities & 0.81 \\
Item 1 & 0.72 \\
Item 6 & 0.69 \\
Item 11 & 0.42 \\
Item 26 & 0.45 \\
Item 32 & 0.81 \\
Item 33 & $\boldsymbol{\alpha}=\mathbf{0 . 6 3}$ \\
\hline Factor 3 Commitment to the & 0.83 \\
Course & 0.62 \\
Item 2 & 0.60 \\
Item 3 & 0.95 \\
Item 16 & 0.33 \\
Item 17 & 0.85 \\
Item 22 & 0.74 \\
Item 24 & total \\
\hline & $\mathbf{0 . 8 1}$ \\
\hline
\end{tabular}

Psico-USF, Bragança Paulista, v. 25, n. 1, p. 1-13, jan./mar. 2020
According to the results presented in Table 6, all the ALAS scores correlated positively with all the AEQ-r scores. The highest correlations were between the total ALAS score and the total AEQ-r, and between the Career (AEQ-r) factors and the Commitment to the Course (ALAS). The moderate-magnitude correlations were (1) between the total ALAS score and all the factors of the AEQ-r; (2) between the Student's Ability factor (ALAS) and the total AEQ-r and the Personal, Career and Study factors (AEQ-r); (3) between the factor Involvement in Non-Compulsory Activities and the total factors of the AEQ-r, Interpersonal, Career, Study and Institutional and, finally, (4) between the factor Commitment to the Course and the total AEQ-r and the Personal, AEQ-r. The weak magnitude correlations were between the ALAS Student's Ability factor and the Interpersonal and Institutional factors of AEQ-r; between the Involvement in Non-compulsory Activities factor of the ALAS and the AEQ-r Personal factor; and lastly, between the ALAS factor Commitment to the Course and the AEQ-r Interpersonal factor.

\section{Discussion}

The objective of the present study was to continue the validation process of the ALAS by verifying its internal structure and the relationship with other related variables. In this sense, evidence of internal validity was investigated in relation to its internal structure and instrument accuracy (factor structure and internal reliability), as well as validity evidence based on relations with other variables, in this case, academic life experiences. It can be seen from the results that the factorial structure found by Vendrami et al., (2004) was not confirmed, since the adjustment indices found were not satisfactory (Damásio, 2012; Hu $\&$ Bentler, 1999), discarding one of the initial hypotheses of this study. Hypotheses regarding how this may have occurred are discussed below. Also, a comparison is made between the factorial structure found by Vendramini et al., (2004) and the factorial structure found in the present study. One possible explanation may be attributed to the influence of $x^{2}$, which is affected by the sample size (Byrne, 2010; Hair, Anderson, Tatham, \& Black, 2009), which, for this study, was half the size of the previous study. Another point to consider relates to differences between samples. For the most part, the present study was comprised of students in daytime classes with a lower average age, who probably had no concurrent activities that could hinder study hours or 
Table 6.

Correlations between ALAS Scores and AEQ-r Scores

\begin{tabular}{lcccccc}
\hline & $\begin{array}{c}\text { AEQ-r } \\
\text { Total }\end{array}$ & $\begin{array}{c}\text { Personal } \\
\text { Factor }\end{array}$ & $\begin{array}{c}\text { Interpersonal } \\
\text { Factor }\end{array}$ & $\begin{array}{c}\text { Career } \\
\text { Factor }\end{array}$ & $\begin{array}{c}\text { Study } \\
\text { Factor }\end{array}$ & $\begin{array}{c}\text { Institutional } \\
\text { Factor }\end{array}$ \\
\hline ALAS Total & $0.69^{* *}$ & $0.51^{* *}$ & $0.33^{*}$ & $0.56^{* *}$ & $0.52^{* *}$ & $0.43^{* *}$ \\
$\begin{array}{l}\text { Factor 1- } \\
\text { Student's Ability }\end{array}$ & $0.52^{* *}$ & $0.43^{* *}$ & $0.24^{* *}$ & $0.36^{* *}$ & $0.45^{* *}$ & $0.28^{* *}$ \\
$\begin{array}{l}\text { Factor 2 - Involvement in } \\
\text { Non-compulsory Activities }\end{array}$ & $0.42^{* *}$ & $0.25^{* *}$ & $0.35^{* *}$ & $0.21^{* *}$ & $0.32^{* *}$ & $0.34^{* *}$ \\
$\begin{array}{l}\text { Factor 3 - Commitment to } \\
\text { the Course }\end{array}$ & $0.59^{* *}$ & $0.44^{* *}$ & $0.11^{*}$ & $0.74^{* *}$ & $0.35^{* *}$ & $0.33^{* *}$ \\
\hline
\end{tabular}

$* \mathrm{p}<.01,{ }^{* *} \mathrm{p}<.001$

class attendance. It is worth noting that, in the study by Vendramini et al., (2004), the students were from the evening courses at a private institution, whose sociodemographic profile is usually different from those enrolled in a public university, which took part in the sample of the present study.

Regarding the factorial structure, since the model proposed by Vendramini et al., (2004) was not confirmed, a new exploratory factor analysis was performed to verify the internal structure of the items. After running the new exploratory factor analysis, the model that was most adequate was a three-factor model. When comparing it with the model of Vendramini et al., (2004), factors 1 and 5 ceased to exist. Factor 1 of that version was called the "University Environment" and Factor 5 "Conditions for Study and Academic Performance". Other factors remained practically intact, with the exception of the "non-compulsory activities" factor which incorporated item 32 that previously was in the "University environment" factor proposed by Vendramini et al., (2004). This was the only factor item eliminated that remained in the new factor structure. However, it evaluates the student's satisfaction with the cultural activities promoted by the university, which are generally considered to be non-compulsory. In this sense, the migration of the item respected the theoretical meaning of the factor to which it moved (Douglass \& Duffy, 2015, Ganguly, 2017, Oliveira et al., 2016).

Regarding the factors "University environment" and "Conditions for study and academic performance" in Vendramini et al., (2004), which disappeared in the new EFA, one hypothesis is that, somehow, they were not strictly related to academic life, a construct that the instrument intended to measure. The university environment, for example, is a broad concept and may depend on the life history of each student, as well as the conditions for study and academic performance (Douglass \& Duffy, 2015, Lamers, Santos, \& Toassi, 2017, Red, 1975). That is, study conditions may vary widely when considering the differences of the samples from both studies, as previously noted. These are possible explanations why the items were not been able to remain after the new EFA round. In the same vein, evaluating constructs regarding Commitment to the Course, Student's Ability, and Involvement in Non-compulsory Activities seemed to be more relevant when they react to academic life in general and, as formulated, the items of these factors appeared to respondents as more related to the likelihood of the student staying and completing the course (Ambiel et al., 2017; Douglass \& Duffy, 2015; Lamers et al., 2017; Valdebenito, 2017).

As for the other validity evidence, the new factor structure presented good internal consistency (Tornimbeni et al., 2008) and also validity evidence based on correlations with measures that evaluate related constructs, in this case, academic experiences. Academic life and academic experiences are equivalent constructs, as recognized in the literature (Fior \& Mercuri, 2009, Fior et al., 2013, Mognon \& Santos, 2013). Thus, the hypothesis of the correlation between the instruments was confirmed, and the highest correlations were between the total scores of the two instruments and between the Career factor of AEQ-r and Commitment to the Course of the ALAS. One possible explanation for the general scores is that when all the variables involved in academic life and academic experiences are added up, there is a great deal of similarity, possibly 
even overlapping one another, because they are highly linked, justifying the correlation of high magnitude found. Also, correlation between Career and Commitment is theoretically consistent, since a student that is confident in the career he intends to pursue, he will engage more in the course, having a greater commitment (Ambiel et al., 2016; Lamers et al., 2017).

Overall, many of the correlations between ALAS and AEQ- $r$ factors were of moderate magnitude, confirming the expected association between both measures. By specifically analyzing the correlations found, the lowest magnitude of correlation identified was between the Commitment to the Course (ALAS) and the Interpersonal factor (AEQ-r). This result makes sense, because although interpersonal relationships may eventually stimulate commitment to the course thanks to the encouragement of colleagues, this does not necessarily occur (Douglass \& Duffy, 2015). In general, the correlations between the three factors of the ALAS and the Interpersonal factor of the AEQ-r were of weak magnitude. An interesting and worrying result to observe is the low-magnitude correlation that occurred between the factor Involvement with Non-compulsory Activities (ALAS) and the AEQ-r Career factor. This is an aspect to be explored in future studies, given the importance that is attached to the broader training of students, so essential to meet the challenges of today's world, where the functional changes have been a constant (Ambiel et al., 2016 Fior \& Mercuri, 2009). By analyzing the correlations in general, the greatest magnitude was detected between the total ALAS score and the total AEQ-r, which pointed to the strength of the validity evidence between correlated measures found in this study.

An instrument that aims to assess the constructs related to academic life becomes relevant by making the prior evaluation of students possible and enabling institutional actions as a way to prevent student attrition, especially in higher education. However, some limitations are present. Despite the attempt to include students from public and private institutions, as well as from different areas of knowledge, the facts that the sample of the present study is only from one Brazilian state, and from a different geographic region and with half of the participants of the study by Vendramini et al., (2004), may be reasons why the factor structure was not confirmed. In future studies, it would be important to test the new factor structure proposed here and re-compare it to the original structure (Vendramini et al., 2004). Thus, it will verify that current results will remain with a larger and more diverse sample, with the suggestion that participants from different states and regions of the country are included so that it is possible to discern if the ALAS shows validity evidence for the Brazilian population. Online application results could be tested, which would facilitate the instrument's use of by public or private institutions of higher education, allowing an increase in the knowledge about the characteristics of the students that attend. Other constructs could also be tested in order to verify their relation with the present instrument, such as motivation and psychological well-being, among others, as well as other types of validity evidence, for example, using academic performance as criterion.

\section{References}

Almeida, L., Marinho-Araujo, C. M., Amaral, A., \& Dias, D. (2012). Democratização do acesso e do sucesso no ensino superior: Uma reflexão a partir das realidades de Portugal e do Brasil. Avaliação: Revista da Avaliação da Educação Superior (Campinas), 17(3), 899-920.

Almeida, L. S., \& Ferreira, J. A. (1999). Adaptação e rendimento acadêmico no ensino superior: Fundamentação e validação de uma escala de validação de vivências acadêmicas. Psicologia: Teoria, Investigação e Prática, 1, 157-170.

Almeida, L. S., Soares A. P., \& Ferreira, J. A. (2002). Questionário de Vivências Acadêmicas (AEQ-r): Avaliação do ajustamento dos estudantes universitários. Avaliação Psicológica, 1(2), 81-93.

Ambiel, R. A. M., Santos, A. A. A., \& Dalbosco, S. N. P. (2016). Motivos para evasão, vivências acadêmicas e adaptabilidade de carreira em universitários. Psico, 47(4), 288-297. doi: 10.15448/1980-8623.2016.4.23872

Astin, A. W. (1999). Student involvement: A developmental theory for higher education. Journal of College Student Development, 40(5), 518-529.

Astin, A. W. (1996). O estudo do impacto causado pela universidade. In: M. H. Castro \& L. A. Rayol (Orgs.), Curso de especialização em avaliação à distância (p. 109-134), Brasília: Editora da UnB.

Astin, H. S., \& Kent, L. (1983). Gender roles in transition: Research and policy implications for higher education. Journal of Higher Education, 54, 309-324. 
Baker, R. W., \& Schultz, K. U. (1992). Measuring expectations about college adjustment. Nacada Journal, 12(2), 23-32.

Byrne, B. M. (2010). Structural equation modeling with AMOS: Basic concepts, applications, and programming (2 Ed.). Nova Iorque: Taylor \& Francis Group.

Chacon, J. M. T., \& Calderón, A. I. (2015). A expansão da educação superior privada no Brasil: Do governo FHC ao governo Lula. Revista Iberoamericana de Educación Superior, 6(17), 78-100. doi: 10.22201/ iisue.20072872e.2015.17.1099

Damásio, B. F. (2012). Uso da análise fatorial exploratória em psicologia. Avaliação Psicológica, 11(2), 213-228.

Douglass, R. P., \& Duffy, R. D. (2015). Calling and career adaptability among undergraduate students. Journal of Vocational Behavior 86(2015), 58-65. doi: 10.1016/j.jvb.2014.11.003

Fior, C. A., \& Mercuri, E. (2009). Formação universitária e flexibilidade curricular: Importância das atividades obrigatórias e não obrigatórias. Psicologia da Educação, 29(2), 191-215.

Fior, C. A., Mercuri, E., \& Silva, D. (2013). Evidências de validade da escala de envolvimento acadêmico para universitários. Avaliação Psicológica, 12(1), 81-89.

Mognon, J. F., \& Santos, A. A. A. (2013). Relação entre vivência acadêmica e os indicadores de desenvolvimento de carreira em universitários. Revista Brasileira de Orientação Profissional, 14(2), 227-237. Recuperado de http://pepsic.bvsalud.org/scielo.php?script $=$ sci_ arttext\&pid=S1679-33902013000200008\&lng=pt \&tlng $=$ pt.

Ganguly, S. (2017). Action research to improve the communication skills of undergraduate students. The IUP Journal of Soft Skills, 11(3), 62-71.

Granado, J. I. F., Santos, A. A. A., Almeida, L., Soares, A. P., \& Guisande, M. A. (2005). Integração académica de estudantes universitários: Contributos para a adaptação e validação do AEQ-r no Brasil. Psicologia e Educação - Portugal, 4(2) 33-43.

Hair, J. F., Anderson, R.E., Tatham, R.L., \& Black, W.C. (2009). Análise multivariada de dados (6 $6^{\mathrm{a}} \mathrm{Ed}$.). Porto Alegre: Bookman.
Hu, L., \& Bentler, P. M. (1999). Cutoff criteria for fit indices in covariance structure analysis: Conventional criteria versus new alternatives. Structural Equation Modeling: A Multidisciplinary Journal, 6(1), 1-55. doi: 10.1080/10705519909540118

Iturra, G. O., Goic, C. E., Astete, E. P., \& Jara, M. O. (2012). Habilidades sociales y rendimiento académico: Una mirada desde el género. Acta Colombiana de Psicologia, 15(2), 21-28.

Lamers, J. M. S., Santos, B. S., \& Toassi, R. F. C. (2017). Retention and dropout on public higher education: A case report of a dentistry-evening course. Educação em Revista, 33, e154730. doi: 10.1590/0102-4698154730

Levin, J., \& Fox, J. A. (2004). Estatística para ciências humanas. São Paulo, SP: Pearson.

Marôco, J. (2014). Análise estatística com o SPSS Statistics. Pêro Pinheiro, Portugal: Report Number.

Oliveira, C. T., Santos, A. S., \& Dias, A. C. G. (2016). College students' perceptions regarding involvement in extra-curricular activities during college. Psicologia: Ciência e Profissão, 36(4), 864-876. doi: 10.1590/1982-3703003052015

Pace, C. R., \& Kuh, G. D. (1998). College student experiences questionnaire. Indiana University.

Pascarella, E. T., \& Terenzini, P. T. (1991). Teorias e modelos de mudanças no estudante universitário. In A. Farah \& R. A. Rezende Neto (Orgs.), Curso de especialização em avaliação à distância (pp. 135-191), Brasília: Editora da UnB.

Pasquali, L. (2015). Delineamento de pesquisa em ciência: Volume 2. São Paulo, SP: Vetor.

Polydoro, S. A. J. (2000). O trancamento de matrícula na trajetória acadêmica do universitário: Condicões de saída e de retorno à instituição. Tese de Doutorado, Campinas: UNICAMP - Faculdade de Educação.

Polydoro, S. A. J., \& Primi, R. (2003). Integração ao ensino superior: Explorando sua relação com características de personalidade e envolvimento acadêmico. Em E. Mercuri \& S. A. J. Polydoro, (Orgs.), Estudante universitário: Características e experiências de formação (pp.41-66). Taubaté: Cabral.

Santos, A. A. A., Polydoro, S. A. I., Vendramini, C., Natário, E., \& Serpa, M. N. (2003).

Psico-USF, Bragança Paulista, v. 25, n. 1, p. 1-13, jan./mar. 2020 
Escala de avaliação da vida acadêmica. Relatório técnico. Itatiba, Universidade São Francisco.

Soares, A. P. \& Almeida, L. S. (2001). Transição para a universidade: Apresentação e validação do questionário de expectativas acadêmicas (QEA). In B. D. Silva \& Almeida, L. S. (Orgs.), Actas do VI Congresso Galaico-Português de Psiocopedagogia. Braga: Universidade do Minho, 899-909.

Soares, A. B., Mourão, L., Santos, A. A. A., \& Mello, T. V. dos S. (2015). Habilidades sociais e vivência acadêmica de estudantes universitários. Interação Psicológica, 19(2), 211-223.

Tinto, V. (1975). Dropout from Higher Education: A theoretical synthesis of recent research. Review of Educational Research, 45(1), 89-125.

Tinto, V. (1997). Classrooms as communities: Exploring the educational character of student persistence. Journal of Higher Education, 68(6), 599-623.
Tornimbeni, S., Pérez, E., \& Olaz, F. (2008). Introducción a la psicometria. Buenos Aires: Paidós.

Valdebenito, M. A. B. (2017). Autoeficacia y vivencias académicas en estudiantes universitarios. Acta Colombiana de Psicología, 20(1), 266-274. doi: 10.14718/ ACP.2017.20.1.13

Vendramini, C. M. M., Santos, A. A. A., Polydoro, S. A. J., Sbardelini, E. T. B., Serpa, M. N. F., \& Natário, E. G. (2004). Construção e validação de uma escala sobre avaliação da vida acadêmica (ALAS). Estudos de Psicologia, 9(2), 259 - 268.

Winston, R. B., Jr., Miller, T. K., \& Prince, J. S. (1987). Student developmental task and lifestyle inventory. Athens, GA: Student Development Associates.

Recebido em: 22/01/2018 Reformulado em: 10/12/2018

Aceito: $21 / 12 / 2018$ 


\section{Annex}

Academic Life Assessment Scale (ALAS)

Item

1) I participate in the cultural and artistic activities promoted by the University

2) I have doubts whether I have chosen the right course

3) I am interested in the professional area activities of the course

4) I can easily compose text

5) I participate in events such as seminars, lectures and study weeks promoted by the University

6) I have difficulty establishing relationships between abstract concepts

7) The knowledge acquired in the schools in which I've studied has been sufficient for my learning at the University

8) I can relate the different disciplines of my course

9) I do not attend social, cultural or sporting events promoted by the University

10) I can easily understand the texts I need to read

11) I cannot clarify my study doubts

12) I think I have the necessary school knowledge to succeed in the course

13) My course does not correspond to my skills and abilities

14) I'm sure I chose the right course

15) I can clarify doubts as to the subjects' content

16) I can concentrate on my studies

17) Course subjects contribute to my professional training

18) The professional area of my course does not interest me

19) Events such as seminars, lectures, study weeks promoted by the University have not favored my training

20) I can read most of the material required in the subjects

21) I am satisfied with the cultural activities proposed by the University

22) I have not attended the academic events (seminars, lectures, study weeks) promoted by the University 23) My personal interests are related to my course

Factor 1 - Student's Ability, items: 4, 6, 7, 8, 10, 11, 12, 15, 16 e 20

Factor 2 - Involvement in Non-compulsory Activities, items: 1, 5, 9, 19, 21 and 22

Factor 3 - Commitment to the Course, items: 2, 3, 13, 14, 17, 18 and 23

Reversed Items: 2, 6, 9, 11, 13, 18, 19 and 22 
About the authors:

Acácia Aparecida Angeli dos Santos - Master in Clinical Psychology from PUC-Campinas. PhD in School Psychology and Human Development from USP. Full Professor of Psychology at the graduate and undergraduate levels at Universidade São Francisco (area of concentration in Psychological Assessment). Productivity 1A scholar at CNPq. Associate-coordinator in the area of Psychology at CAPES.

ORCID: https://orcid.org/0000-0002-8599-7465

E-mail:acacia.santos@usf.edu.br

Francine Náthalie Ferraresi Rodrigues Queluz - Psychologist, Master and PhD in Psychology from the Universidade Federal de São Carlos. She is currently conducting Postdoctoral research in Psychological Evaluation at the Universidade São Francisco. Completed a sandwich stay at Mount Saint Vincent University in Halifax, Canada.

ORCID: https://orcid.org/0000-0002-8869-6879

E-mail:francine.queluz@gmail.com

Ana Carolina Pescarini Gallo - MSc in Education and PhD in Psychology from the Universidade São Francisco. Full professor in the graduation courses of Psychology, Pedagogy, Law, Veterinary Medicine and Dentistry at Universidade Paulista - UNIP/Campinas. General Coordinator of the Campi Campinas of UNIP/ Campinas.

ORCID: https://orcid.org/0000-0002-0798-4810

E-mail: aczilioli.cg@unip.br

Thalyta Hulsen Lemos Veiga - Psychologist graduated from the Centro Universitário de João Pessoa. Master in Psychology (area of concentration in Psychological Evaluation) from the Universidade São Francisco.

ORCID: https://orcid.org/0000-0001-6079-6002

E-mail: lemosveiga@gmail.com

Contact:

Profa. Dra. Acácia Ap. Angeli dos Santos

Programa da Pós-graduação em Psicologia

Rua Waldemar César da Silveira, 105, Vila Cura D’Ars (Swift)

Campinas-SP, Brasil

CEP: $13045-510$

Psico-USF, Bragança Paulista, v. 25, n. 1, p. 1-13, jan./ mar. 2020 